\title{
The Effect of Institutional Factors in Marketing of Agricultural Products by Cooperative Farmers
}

\author{
Obiadi, Adaobi J. ${ }^{1}$, Prof. Nwankwo, Frank O. ${ }^{1}$, Ezeokafor, Uche R. ${ }^{2} \&$ Ekwere, Gabriel E. ${ }^{1}$ \\ ${ }^{1}$ Department of Cooperative Economics and Management, Nnamdi Azikiwe University, Awka. Anambra State. \\ Nigeria \\ ${ }^{2}$ Department of Entrepreneurship Studies, Chukwuemeka Odumegwu Ojukwu University, Igbariam Anambra State, \\ Nigeria \\ Correspondence: Ekwere, Gabriel E., Department of Cooperative Economics and Management, Nnamdi Azikiwe \\ University, Awka, Anambra State, Nigeria. E-mail: etiwistic2@gmail.com
}

Received: February 26, 2020

Accepted: March 26, 2020

Online Published: March 31, 2020

doi:10.5430/bmr.v9n1p43

URL: https://doi.org/10.5430/bmr.v9n1p43

\begin{abstract}
This study was carried out to examine the effect of institutional factors in marketing of agricultural products by cooperative farmers in Anambra State of Nigeria. Four specific objective The study focused on four specific objectives which were to; examine the socio-economic characteristicsof the cooperative farmers and its effect on market participation; determine the quantum and value of agricultural produce that had been marketed; identify the extent to which agricultural market participation of the framer is influenced by institutional factors such as market information, organizational support, use of grades and standards, and legal environment; and make recommendations based on the findings. Three hypotheses were also tested. Descriptive survey design was used for the study where seven hundred and ten (710) was used as sample size. Findings revealed that market disposition of the member was not related to duration of membership which implied that cooperative experience do not have substantial influence on marketing decisions. Farmers affirmed institutional factors such as influence of tradition and cultural practices; legal environment relating to laws governing sale of agricultural products, land tenure system, organizational supports from the government, availability of market information; and use of grades and standards in agricultural marketing significantly influenced their marketing decisions. It was further revealed that institutional factors have no influence on market participation of the cooperative farmers. In conclusion institutional factors have significant influence on marketing decisions while socio-economic characteristics of members have no significant influence on market participation by the cooperative farmers. Based on the findings, it was further recommended that government should always create an enabling environment to encourage farmers to continue to participate in agricultural markets. They can do this by re-examining laws and regulation that appear to impact negatively on farm production and agricultural marketing. This may include abrogation of the land tenure Act that has over the years, hindered access to agricultural farmlands by individual farmers among others.
\end{abstract}

Keywords: Farm produce, institutional factors, marketing, cooperative farmers, cooperative participation, agriculture sector

\section{Introduction}

Agriculture sector is one of the most important sectors in a developing economy, not only because of its contribution to the Gross Domestic Product (GDP) but for employing greater proportion of a country's labour force in productive activities (Adegboye, 2004; Babatunde \& Oyatoye, 2005). In Nigeria, It provides food for the populace and served as one of the major sources of revenue to the country before independence, most especially before crude oil was discovered in large commercial quantity at Oloibiri in 1958. The discovery led to the shift in agricultural production to crude oil exploration. This scenario led to decline in Agricultural production with increasing population growth rate, which consequently led to rising food prices in most Nigerian cities and rural areas (Babatunde \& Oyatoye 2005). Hassan and Omotola (2006) argued that, given Nigeria's resource base, especially in relation to agriculture, she ought not to have food crisis, however, this was never the case. They further noted that this food crisis manifests in the form of quality and quantity of food intake; volume of food production; prices of food; population growth rate; and the earning power of the people. Identification of the development constraints in the agricultural sector is a necessary step 
to unlock the factors inhibiting performance of the sector toward designing policy strategies that would create conducive climate for promoting accelerated commercialization and growth of the sector (Olukunle, 2013). This is where agricultural produce marketing comes in. Agricultural marketing involves getting the agricultural products from the farmers to the consumers. It helps to enlarge production by stimulating consumption, expanding the agro-industry and facilitating industrial growth.

An agricultural marketing system encompasses all the participants or actors in the production, processing and marketing of an undifferentiated or unbranded farm produce (such as cereals), as well as farm input suppliers, farmers, storage operators, processors, wholesalers and retailers involved in the flow of the commodity from initial inputs to the final consumer. The problems faced by agriculture in the sale of surplus goods are quite complex and complicated. The smallholder farmers who have surplus goods have to sell these, generally, in unregulated markets. They, therefore, do not get fair and reasonable price for their products due to a number of reasons. For example the goods produced by the farmers are generally perishable and cannot be stored for a longer period of time. There is less grading of agricultural produce. No market news service is easily available to the farmers. There is a long chain of unscrupulous middlemen who take away much of the hard earned income of the farmers. The transport and storage facilities are not only inadequate but also expensive.

In Nigeria, marketing problems in the agricultural sector are evidenced when farmers, (who are the primary producers and who reside mostly in rural areas) could not get their produce to the market at the right time (thereby incurring considerable post-harvest losses) and are not given better returns for their efforts. This according to Idachaba (2004) causes discouragement and leads to loss of interest in farming and consequently a reduction in agricultural production. Clearly, assurance of fair price is a major determinant for production pattern that guarantees effective market demand (Sharma, 2012). It is therefore believed that rurally based enterprises including rural farmers, can greatly improve their earning potential by adopting a proactive market orientation (Idachaba, 2004). However, it is not always easy to get smallholder farmers to be effective participants in agricultural marketing. This is due to the various challenges that impinge on the agricultural marketing processes. Farm produce deterioration, inadequate processing equipment, poor marketing facilities, high costs of shops, inadequate packaging information are some of the problems of agricultural marketing confronting agricultural produce marketers in south-eastern Nigeria. Other problems associated with agricultural produce marketing as reported by Awoyinka (2009) include scarcity of agricultural marketing information, inadequacy of transport services in rural areas, poor marketing for agricultural produce, inefficient and inadequate storage system. Admittedly, a number of studies have been done on problems of agricultural marketing and factors that impede farmers enthusiasm in participating in the marketing process in Nigeria and elsewhere, but similar studies have not been done in Anambra State hence, the need to embark on this study to identify and analyze the factors that are impeding the ability of smallholder farmers in market participation with specific objectives to; examine the socio-economic characteristicsof the cooperative farmers and its effect on market participation; determine the quantum and value of agricultural produce that are marketed; identify the extent to which agricultural market participation of the framer is influenced by institutional factors such as market information, organizational support, use of grades and standards, and legal environment; and make recommendations based on the findings.

\subsection{Hypotheses}

$\mathbf{H}_{01}$ : The market participation of the cooperative farmer is not significantly related to duration of his membership in cooperative.

$\mathbf{H}_{\mathbf{0 2}}$ : $\quad$ Market participation of the cooperative farmer is not significantly influenced by institutional factors such as market information, organizational supports, legal environment, use of grades and standards.

$\mathbf{H}_{03}$ : $\quad$ Market participation of the farmer is not significantly influenced by his socio-economic characteristics such as age, gender, marital status, household size, education, farm size and income.

\section{Conceptual Framework}

\subsection{Nature of Smallholder Farming}

The concept of smallholder farmer is predicated basically on the size and scale of operation of the farm holding. Defining smallholder farming, Oettle, Fakie, Wentzel, Giddings and Whiteside (1998) upheld that it consists of families or households that produce farm products on relatively small plots of land. In his definition Dent (1989) observed that small farms are usually those farms that are smaller than the average size at national or provincial level. However, Ngemntu (2010) argued that using farm size as the sole criterion for classifying farmers is not sufficient. Supporting this view, Jari (2009) averred that if land size is used alone, it can lead to misconceptions as whether some farmers can be regarded as smallholders or not. For instance, in favorable areas, smallholders may reap larger 
quantities of produce from cultivating less than one hectare of land compared to smallholder farmers in semi-arid areas cultivating more than 10 hectares. Definition of smallholder farmers is indeed place specific, hence it is a concept laden with subjectivity as it is defined variously depending on where it is coming from. For example, it has been observed that the smallholder farming sector is very diverse and difficult to define in South Africa. Their operation is labour intensive rather than capital, resulting in lower productivity when judged with large-scale farms (Kirsten \& vanZyl, 1998).The family depends on the farm for greater part of their food requirements and income. In other words, the objective of most small-scale farmers range from subsistence production to irregular production of surplus for purposes of marketing (Fraser, 1991).

\subsection{Importance of Smallholder Farmers}

Smallholder farmers in developing countries are tremendously important in spite of the unfathomable challenges confronting them. Extant literature agrees that smallholder farmers perform a variety of functions in the agrarian economy. These functions range from contribution to employment creation and increase in income among the rural dwellers, poverty alleviation, linkage for economic growth to contribution towards food security, and equitable distribution of income (Haggblade, Hazell, \& Brown, 1990; South African Ministry of Agriculture and Land Affairs, 1998; Readon \& Barrett, 2000; Dorosh \& Haggblade, 2003). The role of agriculture (through smallholder farmers) in Nigerian economy is, indeed, the same as in most other developing countries. Agriculture, which is dominated by smallholder farmers in Nigeria, is a major contributor to the Gross Domestic Product (GDP) of the nation. It contributes to food security by providing food to the people; smallholder farmers make possible the supply of raw materials needed by the industrial sector; they generate employment opportunities for the country's teeming population; and smallholder farmers are also a major foreign exchange earner for the country through exports (Attah, 2012).

\subsection{Market Participation}

Market participation is described as the inclusion of rural or subsistence farmers into both input and output markets of agricultural products (Holloway \& Ehui, 2002). It is most likely to reduce post-harvest losses and other problems faced by most small scale farmers. It plays essential role in enhancing income and welfare levels for smallholder farmers. Market participation has been observed to generally lead to increase in per capita incomes of households (Omiti, Otieno, Nyanamba, \& McCullough, 2009). The need for improvement in market participation among rural farmers, is critical especially in developing countries like Nigeria where greater percentage of the population dwell in rural areas as poor farmers who produce "the largest portion of the nation's food and exports (OluwasolaIdowu \& Osuntogun, 2008)" (Adenegan, Adepoju, \& Nwauwa, 2012). Among the major reasons why smallholder farmers in developing countries live below poverty line is their inability to access markets easily. This problem has reduced most farmers to subsistence level, and it is not cheering news for growth in agricultural productivity. Indeed, achieving high productivity is half the story, the other part of the story is ability to market agricultural products at better price to the farmer, and this is even of greater importance. Adenegan et al. (2012. p. 28) captured the importance of market participation when they referred to the views of Haggblade (2004) that it is now evident that achieving and sustaining success in productivity based agricultural growth critically depends not only on achieving agricultural productivity and household food consumption but also in increasing better market access and expansion of market opportunities as the livelihood of most African smallholder farmers are often restrained by poor access to markets and limited entrepreneurial skills for adding value to the products (Haggblade, 2004).

Enhanced market participation will not only ensure increased productivity, but will also create opportunities for income generation. Indeed, it has been observed that the need to integrate smallholder farmers into markets "at local, regional and national levels" is of paramount importance (Gani \& Adeoti, 2011).

\subsection{The Role of Institutional Factors in Market Participation by Smallholder Farmers}

Extant literature indicates that smallholder farmers in developing countries such as Nigeria are challenged by a range of institutional and technical problems that affect their ability to make effective choice of marketing channels through which to participate in lucrative agricultural marketing (Jariand Fraser, 2009; Jari, 2009; Ngemntu, 2010). The result is that smallholder farmers who are scattered, mostly, in rural areas experience huge post-harvest losses due to their inability to access markets through effective marketing channel choices. In few instances where they are able to sell their post-harvest surpluses, they do so at abysmally low prices. Ngemntu (2010) agreed that due to lack of veritable knowledge about prices and price trends, most smallholder farmers would accept whatever prices once they are opportune to participate in formal markets. The state of the institutional and technical factors that affect marketing channel choice among smallholder farmers in Nigeria - where a large proportion of rural small-scale farmers depend on traditional and subsistence farming - has made agriculture very unattractive. Most smallholder farmers in Nigeria who dwell in the poverty stricken rural areas find it difficult to make effective choice of marketing channel when they 
have the opportunity to participate in markets. This is due to various constraints inherent in the economy. The current study has chosen to investigate few institutional and technical factors as well as some socio-economic factors which constrain smallholder farmers in Nigeria from taking effective channel choice decisions. Such institutional factors include membership of trade or market association/cooperative society, market information, use of grades and standards, organizational support, and legal environment among others.

\subsection{The Role of Cooperatives}

Most communities are today populated with various types of cooperative societies engaged in both group as well as supported individual activities. Okoli (2006), defined cooperative as an organization for promoting the economic interest of its members. Cooperative is old as man. Some forms of cooperation can be found in all areas of human endeavors activities. According to Oyeniyi (2005), cohesion of a family is based on cooperation; religious, social and traditional groups also strive on cooperation among individual members. It is according to Okoli (2006), a free and voluntary business organization jointly owned by people with identical economic needs and having equal voices in its management and deriving proportionate services and benefits from it. According to Ibe (2002), Cooperatives are one of the possible organizational forms for conducting legitimate business in a market economy where goods are freely bought and sold in the open market. Uzoigwe (2006), summarizes the reasons for forming cooperatives as follows; to provide farmers, with a dependable, honest and accurate market for the products they sell and for the supplies the purchase; and to increase the farmers returns of farm products, supplies and services.

Because most smallholder farmers are restricted from entry into market associations, and are not members of cooperative societies, they lack collective action in markets. Hence they are placed in a disadvantaged bargaining position which often exposes them to price exploitation by unscrupulous traders and agricultural marketing agents. Put differently, inability to have collective action among smallholder farmers makes it difficult for them to make effective marketing channel choice. Indeed, in Nigeria a good number of smallholder farmers are still reluctant to join cooperative societies and take advantage of the obvious benefits therein (Agbonifoh et al., 2007).

\subsection{Theoretical Framework}

The present study is anchored on the Vroom's (1964) Valance-Instrumentality-Expectancy (VIE) theory or expectancy theory. This explains the motivational process as a force determined by three factors which combine in a multiplicative way. The theory states that the intensity of a tendency to perform in a particular manner is dependent on the intensity of an expectation that the performance will be followed by a definite outcome and on the appeal of the outcome to the individual. The Expectancy theory states that employee's motivation is an outcome of how much an individual wants a reward (Valence), the assessment that the likelihood that the effort will lead to expected performance (Expectancy) and the belief that the performance will lead to reward (Instrumentality). In short, Valence is the significance associated by an individual about the expected outcome. It is an expected and not the actual satisfaction that an employee expects to receive after achieving the goals. Expectancy is the faith that better efforts will result in better performance. Thus, the expectancy is the belief that one's effort will result in attainment of desired performance goals. Instrumentality is the belief that if one does meet performance expectations, he will receive a greater reward. Valance refers to the value the individual personally places on the rewards. The VIE theory stipulates that causal relationships exist between motivational process and the levels of expended efforts, achieved performances and allocated awards. Lawler, Porter and Vroom (2009) were emphatic that individuals have different sets of goals and can be motivated if they believe that: Effort-performance relationship is positive: What is the likelihood that the individual's effort be recognized in his performance appraisal? Performance-reward relationship: It talks about the extent to which the employee believes that getting a good performance appraisal leads to organizational rewards. Rewards-personal goals relationship: It is all about the attractiveness or appeal of the potential reward to the individual. The desire to satisfy the need is strong enough to make the effort worthwhile.

The rationale behind the use of expectancy theory in this study is basically to evaluate the motivation for market participation by small scale farmers. Since market participation is intended to bring about increase in farm income of farmers, it therefore follows that availability of enabling environment as could be provided by cooperative marketing society; farmers will be motivated sufficiently to produce for the market.

\section{Materials and Methods}

\subsection{Research Design}

Descriptive survey design was used for this study. This design was adopted for this study because, the purpose of the study is to collect, analyze and report views from cooperative farmers concerning the effect of institutional factors in the marketing of agricultural products by cooperative farmers in Anambra State, Nigeria. 


\subsection{Area of Study}

The geographic scope within which this study was conducted is Anambra State, Nigeria. Anambra State is one of the States in the Southeastern Nigeria. The state lies within the Igbo heartland of the South Eastern geopolitical zone of Nigeria. It was created on August 27th, 1991 with Awka as its capital by General Ibrahim Babangida. Anambra State has a total land area of 4,416 sq kilometers with an estimated population of 4.18 million people (National Population Commission, 2018). Anambra State has 21 local government areas (LGAs) and four agricultural zones (AZs) of Aguata,Awka, Anaocha, and Onitsha. Anambra State is rich in natural gas, crude oil, bauxite, ceramics and almost 100 percent arable soil. Most of its natural resources remain largely untapped. The people are very industrious, and most of the industrial base of the state is private sector driven, spanning from agro-allied, automobile and manufacturing situated mostly in the Nnewi industrial belt. Onitsha market is reputed to be the biggest in West Africa among others.

\subsection{Sample Size Determination}

For the purposes of this study, Farmers Multi-purpose Cooperative Societies (FMCS) were categorized into Anambra North, Anambra South and Anambra Central. Anambra North had 161 FMCS, Anambra Central had 178 FMCS, and Anambra South had105 FMCS. The sample size of FMCS was purposively decided to be $10 \%$.

From each of these 10\% of the FMCS were chosen. The choice of $10 \%$ is supported by Alreck and Settle (1995) who states that it is seldom necessary to sample more than $10 \%$ of the population. Hence, the size of the sample from a total of 445 FMCS from the zones was pegged at 45 (table 1). These 45 FMCS were selected through a process of simple random sampling technique:

Table 1. Population and Sample of FMCS

\begin{tabular}{llllll}
\hline S/N & Zone & No. of FMCS & Sample FMCS & Membership & Sampled members \\
\hline 1 & Anambra North & 161 & 16 & 240 & 240 \\
2 & Anambra Central & 178 & 18 & 360 & 360 \\
3 & Anambra South & 105 & 11 & 110 & 110 \\
\hline
\end{tabular}

Source: Field survey 2020.

The aggregate membership of the selected FMCS which is $\mathbf{7 1 0}$ is less than 1,000 , hence they were all included in the sample.

\subsection{Validity and Reliability of Instruments}

The measuring instrument used in this study was carefully designed in a systematic way that enabled the researcher elicit opinionated, factual and interpretative information pertinent to the purpose and objective of the study after painstaking and constructive critique from colleagues. The instrument was subjected to test - retest pilot study in order to prove the level of reliability of the research instrument.

A pilot study conducted, copies of the questionnaire for the study were administered to 20 (twenty) respondents in Anambra North Senatorial Zone of Anambra State. The same instrument was administered to the same respondents after two weeks. The coefficient of reliability for their responses was established using Pearson Correlation Coefficient. The Pearson Correlation Coefficient showed a reliability value of 0.98 which was considered high enough for the instrument to be reliable.

\subsection{Method of Data Analysis}

Descriptive statistics such as frequency distribution, means and percentages were used to analyze the data obtained to address the objectives of the study. Also inferential statistics, such as One way Analysis of Variance (ANOVA) and multiple regression analysis were employed to address each of the research questions and to test the promulgated hypotheses. Specifically, ANOVA was used to address research question one and to test hypothesis one; while multiple regression models were used to address and to test research questions and hypotheses 2 and 3 as shown below; 


\subsubsection{Regression Models Specification}

The multiple regression analysis that was employed, which involved the classical linear regression technique, using the ordinary least square (OLS) approach.

The necessary regression models which were implicitly specified as follows:

MKTP $_{1}=f($ MINF, GRAD, ORGS, COMM, LEGL, COOPM)

MKTP $_{2}=f(\mathrm{AGE}$, GEND, HSHD, EDUC, FRMSIZ, INCOME)

Where

MKTP = Index of participation in agricultural marketing, measured in terms of proportion of total harvested crop marketed (Naira).

MINF = Market information (Likert mean grade rating).

GRAD = Use of grades and standards (Likert mean grade rating).

ORGS = Organizational support (Likert mean grade rating).

COMM = Communication infrastructure (Likert mean grade rating).

LEGL = Legal environment (Likert mean grade rating).

COOPM = Duration of cooperative membership (years)

AGE $\quad=$ Age of farmer in years

GEND = Gender of farmer (Dummy: female 1, otherwise 0 )

HSHD $=$ Size of farmer's household (no. of persons)

EDUC $\quad$ Years of formal education

FRMSZ $=$ Farm size (in hectares)

INCOM = Total income of farmer in Naira (value of total harvests is used as proxy).

The explicit specifications of models (1) and (2) are given below:

MPRT $_{1}=\alpha+\beta_{1}$ MMAC $+\beta_{1}$ MINF $+\beta_{2}$ GRAD $+\beta_{3}$ ORGS $+\beta_{4}$ LEGL $+\beta_{6} \mathrm{LCOOPM}+\varepsilon_{\mathrm{i}}$

MPRT $_{2}=\alpha+\beta_{1}$ AGE $+\beta_{2}$ GEND $+\beta_{3}$ HSHD $+\beta_{4}$ EDUC $+\beta_{5}$ FRMSZ $+\beta_{6} \mathrm{INCOM}+\varepsilon_{\mathrm{i}}(4)$

The $\alpha$ s and the $\beta$ s are the parameters to be estimated while the $\varepsilon_{\mathrm{i}}$ are the error terms, designed to capture the effects of unspecified variables in the models.

The regression analyses were ran using SPSS package so as to determine the order of importance of the explanatory variables in explaining the variations observed in the dependent variables. The t-tests was performed to test the significance of each of the explanatory variables (and to test hypotheses 2 and 3) at the alpha levels of $5 \%$. Additionally, the joint effects of all the specified variables on market participation was measured through the application of analyses of variance (ANOVA) to obtain F ratios indicating the strength of these effects. Hypothesis one was tested through the application of One Way Analysis of Variance (ANOVA).

\section{Results and Discussions}

\subsection{Socio-Economic Characteristics of Responding Members}

The socio-economic characteristics of the responding farmers are presented in Table 2. The data considered are those relating to gender, age, marital status, educational status, income and cooperative membership duration. Female farmers constituted $69 \%$ of the respondents while the remaining $31 \%$ were female. The high percentage of female members was due to present realities in the rural and agricultural sectors where women are predominantly farmers. Age of the respondents showed that the majority of the respondents (77\%) belonged to the age bracket of 25-50 years, the rest were either above 50 years $(19 \%)$ or below 25 years $(4 \%)$. The marital status of the respondent showed that about 83 percent of them were married, 14 percent were single and the remaining 3 percent were divorced. The educational status of the respondent revealed that about 71 percent had senior secondary school certificate, 18 percent had no formal education, 6 percent had either NCE or OND certificate, and 5 percent had either HND or B.Sc. This implies that the respondents are fairly educated and are in a position to communicate on issues about farming and cooperative benefits. On size of households, majority (61.5\%) had between 3 and 6 members. Twenty eight percent of the households had between 6 and 10 members. The rest had less than 3 members $(2 \%)$ and greater than 10 members $(8 \%)$. 
One half of the respondents (50\%) cultivated between 2 to 4 hectares of land annually, while $28 \%$ cultivated less than 2 hectares. Only $22 \%$ indicated cultivating more than 4 hectares. This implies that the respondents were mostly small scale Farmers.

Table 2. Socio-economic characteristics of Respondents

\begin{tabular}{|c|c|c|c|}
\hline No. & Variables & Frequency & Percentage (\%) \\
\hline \multirow[t]{4}{*}{1.} & Gender & & \\
\hline & Female & 360 & 69.23 \\
\hline & Female & 160 & 30.77 \\
\hline & Total & 520 & 100.00 \\
\hline \multirow[t]{5}{*}{2.} & Age & & \\
\hline & Less than 25 & 21 & 4.04 \\
\hline & $25-50$ & 400 & 76.92 \\
\hline & Above 51 & 99 & 19.04 \\
\hline & Total & 520 & 100.00 \\
\hline \multirow[t]{5}{*}{3.} & Marital Status & & \\
\hline & Single & 13 & 2.50 \\
\hline & Married & 492 & 94.62 \\
\hline & Divorced & 15 & 2.88 \\
\hline & Total & 520 & 100.00 \\
\hline \multirow[t]{6}{*}{4.} & Household Size & & \\
\hline & $<3$ & 12 & 2.31 \\
\hline & $3-6$ & 320 & 61.54 \\
\hline & $7-10$ & 145 & 27.88 \\
\hline & $>10$ & 43 & 8.27 \\
\hline & Total & 520 & 100.00 \\
\hline \multirow[t]{6}{*}{5.} & Educational Status & & \\
\hline & No formal Education & 94 & 18.08 \\
\hline & Senor Secondary School Certificate & 369 & 70.96 \\
\hline & $\mathrm{NCE} / \mathrm{OND}$ & 32 & 6.15 \\
\hline & $\mathrm{HND} / \mathrm{BSC}$ & 25 & 4.81 \\
\hline & Total & 520 & 100.00 \\
\hline \multirow[t]{5}{*}{6.} & Farm Size & & \\
\hline & $<2$ ha. & 148 & 28.46 \\
\hline & 2-4 ha. & 260 & 50.00 \\
\hline & $>4$ & 112 & 21.54 \\
\hline & Total & 520 & 100.00 \\
\hline
\end{tabular}

Source: Field Survey, 2020.

\subsection{Market Disposition of the Farmers}

The total value of crop harvests was an average of N1,112,825.38 per member. The relative contributions of yam, cassava and palm produce to the value of the crop harvests were N422,873.65, N467,386.66, and N222565.08 
respectively. Forty percent of the total harvests, valued at N192,099,644.80 or a mean N369,422.40 per farmer were marketed. The value of marketed crops represented only about $40 \%$ of total harvests; thus suggesting that more than half of harvested crops were either consumed or preserved for the next planting season, meaning that the respondents were largely subsistence farmers. The cooperative societies were shown to be responsible for acting as the channel for market disposal of more than $73 \%$ of marketed crops or $30 \%$ of total harvests. That the cooperative was responsible for the marketing of so many crops on behalf of the members is not surprising agricultural marketing is an integral function of agricultural cooperative. Indeed, farmers when they joined cooperative pledge or agree to deliver at least a portion of harvested crops for cooperatives to dispose in the local or outside markets.

Table 3. Value of Crops harvested and marketed

\begin{tabular}{lllll}
\hline & N & Sum & Mean & Std. Deviation \\
\hline Yam & 520 & 219894296.00 & 422873.6462 & 384513.88274 \\
Cassava & 520 & 243041064.00 & 467386.6615 & 424989.02829 \\
Palm & 520 & 115733840.00 & 222565.0769 & 202375.72776 \\
Total Harvest (Naira) - A & $\mathbf{5 2 0}$ & $\mathbf{5 7 8 6 6 9 2 0 0 . 0 0}$ & $\mathbf{1 1 1 2 8 2 5 . 3 8 4 6}$ & $\mathbf{1 0 1 1 8 7 8 . 6 3 8 7 8}$ \\
Total Marketed (Naira) - B & 520 & 192099644.80 & 369422.3938 & 563696.79723 \\
B as \% of A & 520 & 20854.23 & 40.1043 & 47.77869 \\
Marketed through Coop. - C & 520 & 159376339.27 & 306492.9601 & 554973.31498 \\
C as \% of A & 520 & 15809.79 & 30.4035 & 43.18119 \\
C as \% of B & 520 & 38076.44 & 73.2239 & 17.96991 \\
Valid N (listwise) & 520 & & &
\end{tabular}

Source: Field Survey, 2020.

\subsection{Relating Market Participation by Cooperative Membership Duration}

The study reveals that cooperative experience of members as indicated by their membership durations in agricultural cooperatives has an effect on the market participation of the members as can be seen in table 4. Those farmers who have been members for over 14 years in cooperative have the highest mean value of N628,331.02; while the mean value of others who have been members for between 11 to 14 years, 7 to10 years and 3 to 6 years N378,270.47, $\mathrm{N} 340,147.46$ and N332,719.33 respectively. Respondents who have been members for less than 3 years have mean farm output of $\mathrm{N} 247,348.75$. These indicate that duration of membership in cooperative enhances market participation of members, since older members have more trust and confidence in the cooperative than new members and are able to take advantage of cooperative marketing activities that promote effective produce disposal.

Table 4. Total Crops marketed by Membership duration

\begin{tabular}{|c|c|c|c|c|c|}
\hline Range of Duration (Years) & $\mathbf{N}$ & Mean & Std. Deviation & Minimum & Maximum \\
\hline Under 3 & 10 & $247,348.75$ & $207,100.33$ & $125,755.63$ & $820,800.00$ \\
\hline $3-6$ & 205 & $332,719.33$ & 172429.731 & 37325.82 & $3.17 \mathrm{E}+006$ \\
\hline $7-10$ & 4 & $340,147.46$ & $208,634.22$ & $187,200.00$ & $648,000.00$ \\
\hline $11-14$ & 233 & $378,270.47$ & $130,077.370$ & 30.594 .18 & $3.17 \mathrm{E}+006$ \\
\hline Over 14 & 68 & $628,331.02$ & $122,467.361$ & $39,315.81$ & $3.17 \mathrm{E}+006$ \\
\hline Total & 520 & 369422.3938 & 563696.797 & 30594.18 & $3.17 \mathrm{E}+006$ \\
\hline
\end{tabular}

Source: Field Survey, 2020. 


\subsection{Test of Hypotheses}

\subsubsection{Hypothesis One}

$\mathbf{H}_{01}$ : The market disposition of the cooperative farmer is not significantly related to duration of his membership in cooperative.

The total value of agricultural produce marketed is examined vis-a-vis duration of cooperative membership of farmers are examined vide a One way ANOVA. The results are presented in table 5 below. The results of the One way ANOVA in table 5 shows that the cooperative membership variable when examined with the value of produce marketed an $\mathrm{F}$ ratio value of 1.189 obtained was not significant at the conventional 5\% level. As a result of this, the null hypothesis one as stated above is accepted and we conclude that the market disposition of the cooperative farmer is not significantly related to duration of his membership in cooperative. The implication of this is that a farmer's disposition to participation in agricultural marketing may be influenced by his cooperative membership but not necessarily the number of years he has been a member.

Table 5. One Way ANOVA Market Produce and Cooperative Membership Duration

Total Produce Marketed

\begin{tabular}{llllll}
\hline & Sum of Squares & Df & Mean Square & F & Sig. \\
\hline Between Groups & 3764720383915.26 & 10 & 376472038391.526 & 1.189 & .295 \\
Within Groups & 161149646722816.84 & 509 & 316600484720.662 & & \\
Total & 164914367106732.10 & 519 & & & \\
\hline
\end{tabular}

Source: Field survey, 2020.

\section{Factors affecting marketing of crops; Influence of Institutional Factors on marketing Decisions}

On the perceptions of the respondents on the influence of institutional factors on marketing decisions, the mean responses to the five items in table 6 shows that there is a commonality of agreement that the indicated factors have influence on the farmers decision to market or not to market harvested farm crops. All the responses had mean ratings of at least 3.2. The grand mean of the responses was also found to be greater than 3.0. The relative importance of the items could also be assessed from the magnitude of their individual mean scores. Thus, the most important item of influence was "influence of tradition and cultural practices". This was followed by legal environment relating to laws governing sale of agricultural products, land tenure system, oorganizational supports from the government; availability of market information; and use of grades and standards in agricultural marketing; in that order. The implication of this is that institutional factors within the marketing environment domain could have substantial influence on rural agricultural marketing.

Table 6. Respondents perception of institutional factors affecting marketing decisions

\begin{tabular}{llcccc}
\hline S/N & Items & Sum & Mean & $\begin{array}{l}\text { Std } \\
\text { Dev. }\end{array}$ & Decision \\
\hline 1 & Availability of market information & 1761.00 & 3.3865 & 0.80138 & Agree \\
2 & Organizational supports from the government & 1779.00 & 3.4212 & 0.59988 & Agree \\
3 & Use of grades and standards in agricultural marketing & 1665.00 & 3.2019 & 0.81152 & Agree \\
\multirow{2}{*}{4} & $\begin{array}{l}\text { Legal environment relating to laws governing sale of agricultural } \\
\text { products, land tenure system, etc. }\end{array}$ & 1843.00 & 3.5442 & 0.50998 & Agree \\
5 & Influence of tradition and cultural practices & 1874.00 & 3.6038 & 0.56622 & Agree \\
\hline & Grand mean & 1784.40 & 3.4315 & 0.59068 & Agree
\end{tabular}

Source: Field survey, 2020. 


\section{Effects of Institutional Factors (Regression Analysis)}

The estimates of $\mathrm{R}^{2}$ and Adj. $\mathrm{R}^{2}$ suggest that all the variables in the model collectively accounted for more than $72 \%$ of the variations in marketed crops by the respondents. The $\mathrm{F}$ ratio value of 226.500 was significant at $1 \%$ level. All the variables had expected positive signs suggesting direct relationships with marketed crops. However, only coefficients of organizational support, legal environment, tradition and culture were significant at the expected levels. This therefore suggests that three variables were the most important factors that influence marketing decisions among the farmers.

Table 7. Regression Estimates (Influence of institutional factors on market participation)

\begin{tabular}{llll}
\hline Model & Coefficient Estimates & t-Value & Significance \\
\hline (CONSTANT) & 0.256 & 2.749 & 0.006 \\
$X_{I}$ (Market information) & 0.042 & 1.536 & 0.125 \\
$X_{2}$ (Organizational support) & 0.080 & 2.323 & 0.021 \\
$X_{3}$ (Grades \& standards) & 0.006 & .242 & 0.809 \\
$X_{4}$ (Legal environment) & 0.349 & 7.010 & 0.000 \\
$X_{5}$ (Tradition and culture) & 0.407 & 12.537 & 0.000 \\
$X_{5}$ (Coop. Experience) & 0.032 & 1.382 & 0.167 \\
\hline$R^{2}$ & 0.726 & & \\
Adj $R^{2}$ & 0.723 & & \\
$F$ & 226.500 (Sig. @ 0.001) & & \\
\hline
\end{tabular}

Dependent Variable: Marketed crops.

\subsubsection{Test of Hypothesis Two}

$\mathbf{H}_{\mathbf{0 2}}$ : Market participation of the farmer is not significantly influenced by institutional factors such as institutional factors such as market information, use of grades and standards, organizational supports, and legal environment.

The test of hypothesis two was accomplished through the application of the regression result in table 7 above. The result shows that all the socio-economic variables jointly explain more than $721 \%$ of the variations in marketed produce. The $\mathrm{F}$ ratio associated with this was only 226.5 which were significant at $1 \%$ level. The null hypothesis is therefore rejected and the alternate, "market participation by the farmer is significantly influenced by institutional factors such as market information, use of grades and standards, organizational supports, and legal environment were accepted. The above finding is a confirmation of similar studies by Jari(2009),Terfa, Haile, Baker and Kassie (2012) in Ethiopia which found access to market information, organizational factors among others as being significant of market participation.

\section{Influence of Farmers' Socio-economic Factors on Market Participation.}

As a follow up to the findings on market participation determinants, a multiple regression analysis was also carried out to measure the effect of socio-economic characteristics of the farmers on marketed crops (table 8). The estimates of $\mathrm{R}^{2}$ and Adj. $\mathrm{R}^{2}$ suggest that all the variables in the model collectively accounted for less than $1 \%$ of the variations in market crops by the respondents. The F ratio was not significant at the conventional level. Indeed none of the socio-economic characteristics such as age, gender, household size, education and farm size were significant at the conventional $5 \%$ level. Clearly, these findings show that decision to market agricultural produce is often not dictated by ones socio-economic background. 
Table 8. Regression Estimates (socio-economic determinants of market participation)

\begin{tabular}{llll}
\hline Model & Coefficient Estimates & t-Value & Significance \\
\hline (CONSTANT) & 2.941 & 28.134 & 0.000 \\
$X_{I}$ (Age) & 0.000 & 0.243 & 0.808 \\
$X_{2}$ (Gender) & 0.037 & 0.881 & 0.379 \\
$X_{3}$ (Household size) & 0.006 & 0.875 & 0.382 \\
$X_{4}$ (Education) & 0.004 & 0.826 & 0.409 \\
$X_{5}$ (Farm size) & 0.015 & 0.961 & 0.337 \\
\hline$R^{2}$ & 0.006 & & \\
Adj $R^{2}$ & 0.003 & & \\
$F$ & 0.647 (Sig. @ 0.664) & & \\
\hline
\end{tabular}

Dependent Variable: Marketed crops.

\subsubsection{Test of Hypothesis Three}

$\mathbf{H}_{\mathbf{0}}$ : Marketing participation of the farmer is not significantly influenced by socio-economic characteristics such as age, gender, marital status, household size, education, farm size and income.

The test of hypothesis two was accomplished through the application of the regression result in table 8 above. The result showed that all the socio-economic variables jointly explain less than $1 \%$ of the variations in market produce. The F ratio associated with this was only 3.69 which were not significant at the conventional $5 \%$ level. The null hypothesis is therefore accepted and we conclude that socio-economic characteristics of the members were not significant determinants of marketing decisions of the responding farmers.

Clearly, the above finding is at variance with the ones by Chete (2013) in Oyo State and the one by Adenegan, Adekpolu and Nwauwa (2012) which found such socio-economic variables such as quantities of farm produce, marital status, household size, farm experience etc. as significant determinants of market participations. A reasonable explanation here could be that members of cooperatives are obliged to deliver a certain minimum of their harvests to their cooperatives to market. Thus, minimising the effects of socio-economic factors on marketing participation.

\section{Discussion of Findings}

Arising from the study, finding revealed that female farmers constituted a majority of the respondents. Most of the farmers were aged between 25 and 50 and are mostly married. Their educational profiles showed that there are fairly educated with more than $70 \%$ having had senior secondary school certificate. Majority of the respondents had household sizes of between 3 and 6; and cultivated average farm land of 2 to 4 hectares. The total value of crop harvests were $\mathrm{N} 578,669,200.00$ or an average of $\mathrm{N} 1,112,825.38$ per member of which only $40 \%$ were marketed. The cooperative societies were responsible for marketing more than $73 \%$ of total marketed produce or $40 \%$ of total crop harvests. The study also revealed that cooperative experience of members as indicated by their membership durations in agricultural cooperatives has positive influence on the market participation of the members. Farmers who have been members for over 12 years in cooperative have the highest mean value of marketed crops $(\mathrm{N} 1,661,266)$ while the mean value of others who have been members for between 9 to 12 years, 6 to 9 years and 3 to 6 years N1,401,103.57, $\mathrm{N} 1,059,797.59$ and $\mathrm{N} 1,180,810.37$ respectively.

Hypothesis one which stated that market disposition of the member was not related to membership duration was accepted at the 5\% conventional level ( $\mathrm{F}$ ratio $=1.189$; Sig. 0.295 ). Thereby suggesting that cooperative experience do not have significant influence on marketing decisions. The responding farmers affirmed that institutional factors such as influence of tradition and cultural practices; legal environment relating to laws governing sale of agricultural products, land tenure system, organizational supports from the government; availability of market information; and use of grades and standards in agricultural marketing had influence on their marketing decisions. Hypothesis two which stated that institutional factors had no influence on market participation was rejected at the $1 \%$ level of significance (F ratio 226.5; Sig.; 0.01). The conclusion was that institutional factors had significant influence on marketing decisions. Hypothesis three which stated that socio-economic characteristics of members had no influence on market 
participation was accepted at the $5 \%$ level of significance (F ratio 0.647 ; Sig.; 0.664). The conclusion here was that socio-economic factors have no significant influence on marketing decisions.

\section{Conclusion}

One of the major functions of agricultural cooperatives is to provide the platform for members to effectively participate in agricultural produce market. This study having evaluated the effect of institutional and other factors on marketing of agricultural products by cooperative farmers in Anambra State will instructively conclude that institutional factors such as tradition and cultural practices; legal environment relating to laws governing sale of agricultural products, land tenure system, organizational supports from the government; availability of market information; and use of grades and standards in agricultural marketing had significant influence on market participation by cooperative farmers. And their socio-economic characteristics are not significant determinants to market participation by cooperative members. Based on these findings, it is recommended that there should be regular improvement of cooperative and farmer education and training among farmers. This will not only impact on volume of agricultural output but will also improve the farmers' knowledge on markets and cooperative as an important marketing channel. There is also a need for the government to create enabling environment to encourage farmers to continue to participate in agricultural markets. They can do this by re-examining laws and regulation that appear to impact negatively on farm production and agricultural marketing. This may include abrogation of the land tenure Act that has over the years hindered access to agricultural farmlands by individual farmers. There is also the need to abrogate obnoxious levies and tolls in the rural market by local government official in the name of internally generated revenues (IGR), which have discouraged poor farmers with small quantities of harvested crops to market. And massive grass root campaign by the government and the cooperative societies is necessary to promote formation and joining of agricultural cooperative farmers. Since, it has been proved that membership of cooperatives improves the welfare of farmers and that cooperative is a reliable platform or channel for agricultural marketing, progress will be made if many farmers are made join.

\section{References}

Adegboye, R. O. (2004). Land, agriculture and food security in Nigeria. 3rd Faculty Lecture, Faculty of Agriculture, University of Ilorin, Nigeria.

Adenegan, K. O., Adepoju, A., \&Nwauwa L. O. E. (2012). Determinants of market participation of maize farmers in Rural Osun State of Nigeria. International Journal of Agricultural Economics and Rural Development, 5(1), 28-39.

Agbonifoh, B., Ogwo, E., Nnolim, D., \& Nkamnebe, A. (2007) Marketing in Nigeria: concepts, principles and decisions. African Journal of Business Management, 2(12), Retrieved from http://www.academicjournals. org/AJBM

Attah, A. D. (2012). Food security in Nigeria: The role of peasant farmers in Nigeria. African Research Review, 6(4), 27, 173-190. https://doi.org/10.4314/afrrev.v6i4.12

Awoyinka Y. A. (2009). Effect of presidential initiatives on cassava production efficiency in Oyo State, Nigeria. Ozean Journal of Applied Sciences, 2(2), 185-193.

Ayinde, I. A. (2005). Market dynamics for cowpeas: weight and measurement issuesinKuto market, Abeokuta, Nigeria Report submitted as part of the market study on: Building a food marketing policy evidence base in Nigeria, Ogun State, Nigeria. University of Agriculture.

Babatunde, D. S., \& Oyatoye, I. S. (2005). Market dynamics for cowpeas: weight and measurement issuesinKuto market, Abeokuta, Nigeria Report submitted as part of the market study on: Building a food marketing policy evidence base in Nigeria, Ogun State, Nigeria. University of Agriculture.

Dent, R. J. (1989). Sustainable Agriculture for Small-scale Farmers: A Farming System Perspective. Bangkok: Faculty of Agriculture, Kasetsart University, Thailand.

Dorosh, P., \& Haggblade, S. (2003). Growth linkages, price effects and income distribution in sub-Saharan Africa. IFPRI, Washington DC. Journal of African Economies, 12(2), 207-235. https://doi.org/10.1093/jae/12.2.207

Fraser, G. C. G. (1991). Agricultural marketing in less developed countries with special reference in Ciskei. Unpublished DoctoralThesis, University of Stellenbosch, Stellenbosch.

Gani, B. S., \& Adeoti, A. I. (2011). Analysis of market participation and rural poverty among farmers in northern part of Taraba State, Nigeria. Journal of Economics, 2(1), 23-36. https://doi.org/10.1080/09765239.2011.11884934 
Haggblade, S., Hazell, P., \& Brown, J. (1990). Farm-on-farm linkages in rural sub-Saharan Africa. World Development, 17(8), 1173-1201. https://doi.org/10.1016/0305-750X(89)90232-5

Haggblade, S. (2004). Successes in Africa Agriculture: Results of an expert survey. World Development, 32(5), 745-766. https://doi.org/10.1016/j.worlddev.2003.11.004

Hassan, S., \& Omotola, S. J. (2009). Foreign aid, debt relief and Africa's development: problems and prospects. South African Journal of International Affairs, 16, 1, 87-102. https://doi.org/10.1080/10220460902986180

Holloway, G. J., \& Ehui, S. (2002). Expanding market participation among smallholder livestock producers. Paper presented in Seminar on Socio-economic and Political Research in Nairobi, October 15 - 17.

Idachaba, F. S. (2004). Food Security in Nigeria: Challenges Under Democratic Dispensation, 9th ARMTI Annual Lecture, Ilorin, 24/3/2004.

Jari, B., \& Fraser, C. G. (2009). An analysis of institutional and technical factors influencing agricultural marketing amongst smallholder farmers in the Kat River Valley, Eastern Cape Province, South Africa. African Journal of Agricultural Research, 4(11). 1129-1137.

Jari, B. (2009). Institutional and technical factors influencing agricultural marketing channel choices amongst smallholder and emerging farmers in the Kat River Valley (Master Thesis, University of Fort Hare Alice, South Africa).

Kirsten, J. F., \& VanZyl, J. (1998). Defining small-scale farmers in the South African context. Agrekon, 37(4), 560-571. https://doi.org/10.1080/03031853.1998.9523530

Lawler, E., Porter. L., \& Vroom, V. (2009). Motivation and management Vroom's expectancy theory. Value Based Management Website. Retrieved January 28, 2012 from: http://www.valuebasedmanagement.net/methods_vroom_expectancy_theory.htmlhttp://www.valuebasedmanag ement.net/methods_vroom_expectancy_theory.html

National Population Commission. (2018). Report of the census review committee. Abuja, Nigeria.

Ngemntu, S. T. (2010). An Investigation of the Production and Marketing Challenges Faced by Smllholder Farmers inAmahlathi Municipality: A Case Study of Zanyokwe Irrigation Scheme and Silwindlala Women's Project. Masters Thesis, University of Fort Hare Alice, South Africa.

Oettle, N., Fakir, S., Wentzel, W., Giddings, S., \& Whitesid, M. (1998). Encouraging sustainable smallholder agriculture in South Africa. Environment and Development Consultancy Ltd., Hillside. In Jari, B. (2009). Institutional and technical factors influencing agricultural marketing channel choice among smallholder and emerging farmers in the Kat River Valley. Masters Thesis, University of Fort Hare Alice, South Africa.

Ogunleye, K. Y., \& Oladeji, J. O. (2007). Choice of cocoa market channels among cocoa farmers in Ila Local Government Area of Osun State, Nigeria. Middle-East Journal of Scientific Research, 2(1), 14-20.

Oluwasola, O., Idowu, E. O., \& Osuntogun, D. A. (2008). Increasing agricultural household incomes through rural-urban linkages in Nigeria. African Journal of Agricultural Research, 3(3), 566-573.

Olukunle, T. O. (2013). Challenges and Prospects of Agriculture in Nigeria: The Way. Journal of Economics and Sustainable Development, 4, 16.

Omiti, J. M., Otieno, D. J., Nyanamba, T. O., \& McCullough, E. (2009). Factors influencing the intensity of market participation by smallholder farmers: A case study of rural and peri-urban areas of Kenya. African Journal of Agricultural Research, 3(1), 57-82.

Onyebinama, U. (2004). Land Reform, Security of Tenure and Environmental Conservation in Nigeria. International Journal of Agriculture and Rural Development, 5(1), 86-90. https://doi.org/10.4314/ijard.v5i1.2567

Readon, T., \& Barrett, C. (2000). Agro-industrialization, globalization, and international development: An overview of issues, patterns and determinants. Journal of Agricultural Economics, 23(3), 195-205. https://doi.org/10.1111/j.1574-0862.2000.tb00272.x

Sharma, T. (2012). Overcoming transaction costs barriers to market participation of smallholder farmers in Northern Province of South Africa. Unpublished Doctoral dissertation, University of Pretoria, Pretoria, South Africa. 
South African Ministry of Agriculture and Land Affairs (1998). Agricultural Policy, South African Government.

Uzoigwe, D. C. (2006). Economic Development in Nigeria through the Agricultural, Manufacturing and Mining Sectors: An Econometric Approach (Unpublished PhD Thesis 2016).

Vroom, V. H. (1964). Work and motivation. New York: Wiley. 